\title{
IMPROVING THE LEVEL OF ORGANIZATIONAL CULTURE IN COMPANIES DUE TO THE CONFLICT REDUCTION
}

\section{ПІДВИЩЕННЯ РІВНЯ ОРГАНІЗАЦІЙНОЇ КУЛЬТУРИ В КОМПАНІЯХ ЗА РАХУНОК ЗНИЖЕННЯ КОНФЛІКТНОСТІ}

\author{
Myronova Olga \\ Simon Kuznets Kharkiv National University of Economics \\ ORCID: https://orcid.org/0000-0002-3188-2881
}

\author{
Миронова Ольга Миколаївна \\ кандидат економічних наук, доцент, \\ Харківський національний економічний університет імені Семена Кузнеця
}

\begin{abstract}
The article is devoted to substantiating the need to reduce the level of conflict in modern companies to ensure an effective organizational culture. The essence of conflict as a social phenomenon is analyzed. The main preconditions for conflicts in companies are considered. The relationship between the level of conflict in the company and the level of its organizational culture has been studied. Theoretical generalization of methods for reducing the level of conflict is carried out. The role of the leader in reducing the level of conflict in the company is substantiated and the list of necessary actions and skills of the leader in this process is offered. Based on the above methodology, the level of conflict of the researched small company is determined and the type of its organizational culture is clarified. The main negative points that are present in the organizational culture of the company are highlighted. A list of measures to reduce the level of conflict is proposed. A forecast on the results of the implementation of the developed program to reduce the level of conflict in the studied company is performed.
\end{abstract}

Keywords: conflict, organizational culture, leader, level of conflict, methods of conflict reduction.

Стаття присвячена обґрунтуванню необхідності зниження рівня конфрліктності в сучасних компаніях для забезпечення ефективної організаційної культури. Сьогодні не викликає сумніву в важливості ефективного управління персоналом. Одним із елементів його забезпечення $€$ формування ефективної організаційної культури. На рівень організаційної культури компанії впливає багато факторів, в тому числі й рівень конфрліктності. Для отримання високого рівня організаційної культури необхідно забезпечити низький рівень консрліктності. у дослідженні проаналізовано сутність консрлікту як соціального феномену. Запропоновано визначати конфрлікт як зіткнення протилежно спрямованих, несумісних одна з одною тенденцій у свідомості окремо взятого індивіда, у міжособистісних взаємодіях індивідів, або груп людей, які пов'язані з гострими негативними емоціями, переживаннями Розглянуто основні передумови виникнення конфрліктів у компаніях. Досліджено зв'язок між рівнем конфрліктності в компанії та рівнем ії організаційної культури. Визначено, що високий рівень конфрліктності призводить до погіршення організаційної культури в компанії. Проведено теоретичне узагальнення методів зниження рівня конорліктності. Серед них визначено дві групи методів: структурні та міжособистісні. Обґрунтовано роль лідера у зниженні рівня конфрліктності в компанії та запропоновано перелік необхідних дій та навиків лідера у цьому процесі. Серед них можна виділити такі, які вміння слухати, акцентування уваги на предметі конфрлікту та намагання об'єднати всіх учасників конфрлікту для його вирішення. На основі наведеної методики досліджено рівень консрліктності досліджуваної невеликої компанії та виявлено, що він знаходиться на високому рівні. Також з'ясовано тип її організаційної культури. Виокремлено основні негативні моменти, які присутні в організаційній культурі компанії. Для зменшення негативних аспектів запропоновано перелік заходів щодо зниження рівня конфрліктності. Зроблено прогноз щодо результатів запровадження розробленої програми щодо зниження рівня консрліктності в досліджуваній компанії.

Ключові слова: конфрлікт, організаційна культура, лідер, рівень конфрліктності, методи зниження консрліктності.

Статья посвящена обоснованию необходимости снижения уровня конорликтности в современных компаниях для обеспечения эфрфективной организационной культуры. Проанализирована сущность конфликта как социального феномена. Рассмотрены основные предпосылки возникновения конфрликтов в компаниях. Исследована связь между уровнем конфрликтности в компании и уровнем ее организационной культуры. Проведено теоретическое обобщение методов снижения уровня конфрликтности. Обоснована роль лидера в снижении уровня консрликтности в компании и предложен перечень необходимых действий и навыков лидера в 
этом процессе. На основе приведенной методики определен уровень конфрликтности исследуемой небольшой компании и выяснено тип ее организационной культуры. Выделены основные негативные моменты, которые присутствуют в организационной культуре компании. Предложен перечень мероприятий по снижению уровня конфрликтности. Сделан прогноз относительно результатов внедрения разработанной программы по снижению уровня конфликтности в исследуемой компании.

Ключевые слова: конфрликт, организационная культура, лидер, уровень конфрликтности, методы снижения конфрликтности.

Problem statement. Personnel management is a complex, purposeful impact on the team in order to ensure optimal conditions for the creative, proactive, conscious work of its individual employees, aimed at achieving the goals of the company. In the conditions of the formation of a market economy, the issues of practical application of modern forms of personnel management, which make it possible to increase the socio-economic efficiency of any enterprise, acquire particular importance. Today, special attention is paid to raising the level of organizational culture as an important element of the personnel management in each company. The organizational culture concentrates the policy and ideology of the organization, the system of its priorities, the criteria of motivation and distribution of power, the characteristics of social values and norms of behavior. Elements of organizational culture are a reference point in the management of the organization of management decisions, establishing control over the behavior and relationships of employees in the process of assessing industrial, economic and social situations [1]. One of the aspects of ensuring a high level of organizational culture in the company is the management of conflicts. During business activities employees often encounter situations that cause certain conflicts. However, it is very important to understand that conflicts could and should be managed. This will either completely resolve conflict situations or at least reduce the level of conflict in the company. Thus, it is necessary to research and develop measures to reduce the level of conflict in companies to ensure a high level of organizational culture

Analysis of recent research and publications. Theoretical and scientific-methodological aspects of organizational culture are reflected in the works of such domestic and foreign scholars as A. Brown, A. Melnyk, G. Zakharchin, I. Parfenova, O. Kharchyshyna, T. Sazonova, I. Shul'zhenko, E. Schein and others. In most studies, organizational culture is considered through its functions. The most common among the functions of organizational culture it is possible to identify these: integrational, motivational, regulative, adaptive, protective. Additional or specific functions include such functions as: cognitive-informational, communicative, qualitative, educational and developmental, consumer-oriented function, regulation of partnerships, adaptation to society's needs, etc. [2]. Among other functions, some researchers single out the function of reducing conflicts among the functions of organizational culture. Also, aspects of conflict management during the improvement of organizational culture are given considerable attention in the works of such authors as T. Sazonova, V. Khavroniuk [4], V. Sarafannikov, S. Sobakar [6], M. Honchar, Yu. Bilyk [5], I. Shul'zhenko $[4 ; 6]$, and others. They emphasize that in order to ensure the effectiveness of the company in the context of its organizational culture, it is necessary to take measures to manage conflicts and reduce stress among employees of the organization. In their works they analyze the causes of conflicts, the mechanisms of their occurrence, investigate the impact of organizational culture on the conflict management system, investigate the factors of increasing the resilience of employees. But at the same time, they didn't suggest practical recommendations for reduction the conflict level in the companies. Based on existing publications, it can be concluded that the management of companies is still a completely unresolved issue of reducing the level of conflict in the context of improving organizational culture.

Formulation of the goals of the article. The purpose of the article is to investigate the scientific provisions and develop practical recommendations for reducing the conflict level in order to organizational culture improvement.

The main research material. Conflict is a complex social phenomenon characterized by many parameters. The most important of them: the subject of the conflict, its object, subjects, conflict situation, incident, structure. An important characteristic of the conflict is also its dynamics. Since conflict as a process is often repeated, knowledge of this conflict area will help to timely contain and resolve the conflict at a certain stage of its development. This is especially important in the managing the organizational culture in the company.

Modern theory and practice of conflict studies show that in real life people often perceive and 
evaluate certain events differently, and this often leads to controversial situations. If the situation that arises poses a threat to achieve the goal of even one of the participants in the interaction, then a conflict arises. To clarify the essence of the conflict, it is important to identify its main features, to formulate the conditions of its occurrence. Conflict always arises on the basis of opposing motives and judgments, which can be considered a necessary condition for conflict. Conflict is always characterized by the confrontation of the subjects of social interaction, which is manifested through the infliction of mutual damage (moral, material, physical, psychological, etc.).

There are a lot of definitions of the conflicts. Let's consider some of them in details. In [7] M. Prymush considers the conflict as the relationship between the subjects of social interaction, which is characterized by their confrontation on the basis of opposing motives (needs, interests, goals, ideals, beliefs) or thoughts (thoughts, views, assessments, etc.). American sociologist L. Cozer [8] defined conflict as a struggle for values and claims to a certain status, power, resources, the purpose of which is to neutralize, destroy the opponent or harm him. F. Borodkin and N. Korjak in [9] define conflict as a clash of oppositely directed goals, interests, positions, opinions or views of two or more people. In this definition, the emphasis is on differences in the form of goals, interests, and the question of methods for resolving them is not disclosed.

Thus, agreeing with all the above definitions, conflict is a clash of oppositely directed, incompatible trends in the minds of an individual, in interpersonal interactions of individuals or groups of people associated with acute negative emotions, experiences.

It should be noted that the essence of the conflict has aroused the interest of scientists for a long time. However, different scientists have seen the nature of this phenomenon differently. In this case, proponents of the school of "human relations" believed that conflict is evil and should be avoided. Determining the possibility of contradictions between the goals of the individual and the organization, between the linear and functional links, between the powers and capabilities of officials, etc., they considered the conflict as a sign of ineffective activities of the organization and management system. Thus, in their opinion, conflicts do not arise if the organization has a good relationship between its members. Modern views on the nature of conflicts are that even with effective management in organizations, some conflicts are not only possible but even desirable. Of course, conflict is not always positive. In some cases, it can interfere with meeting the needs of the individual and even achieve the goals of the organization. However, in many cases, the conflict helps to identify diversity of views, provides additional information, helps to identify alternative solutions to problems. This makes the group decision-making process more efficient and gives people the opportunity to satisfy their own problems in respect and in power. It can also lead to more effective implementation of plans, strategies and projects, increasing the level of organizational structure.

Since organizational culture is a system of norms, values, rituals, rules, which govern the activities of company's staff, and the conflict arises, including due to contradictions with these elements of organizational culture, there is a need for detailed study of these aspects to ensure conflict and improving organizational culture.

There are different ways to reduction conflict level in a company. The main ways to resolve conflicts are structural and interpersonal methods (Figure 1). Structural methods of conflict resolution include: clarification of labor requirements, coordination and integration mechanisms, overall organizational goals, the structure of the reward system. Interpersonal methods of conflict resolution include: avoidance, smoothing, coercion, compromise, problem solving.

The leader plays an important role in resolving conflict situations in the company. First of all, it is necessary to realistically assess and analyze the conflict situation, which means that the leader must:

(1) distinguish the direct motive of the conflict from its cause, which is often hidden by the participants in the conflict situation;

(2) understand the subjective motives for people to enter a conflict situation. To do this, it is needed to know the life path of workers, especially at the last time, their views and beliefs, interests;

(3) determine the direction of specific actions of the parties in the conflict situation. These actions reflect the motives of human participation in a conflict situation;

(4) determine the objective area of the conflict. Here it is needed to identify the subject of the contradiction concerns the technology of production, the system of organization and remuneration of labor, the features of business and personal relationships of conflicting persons. This will allow to simultaneously establish the nature of interpersonal conflict and partially localize its scope. 


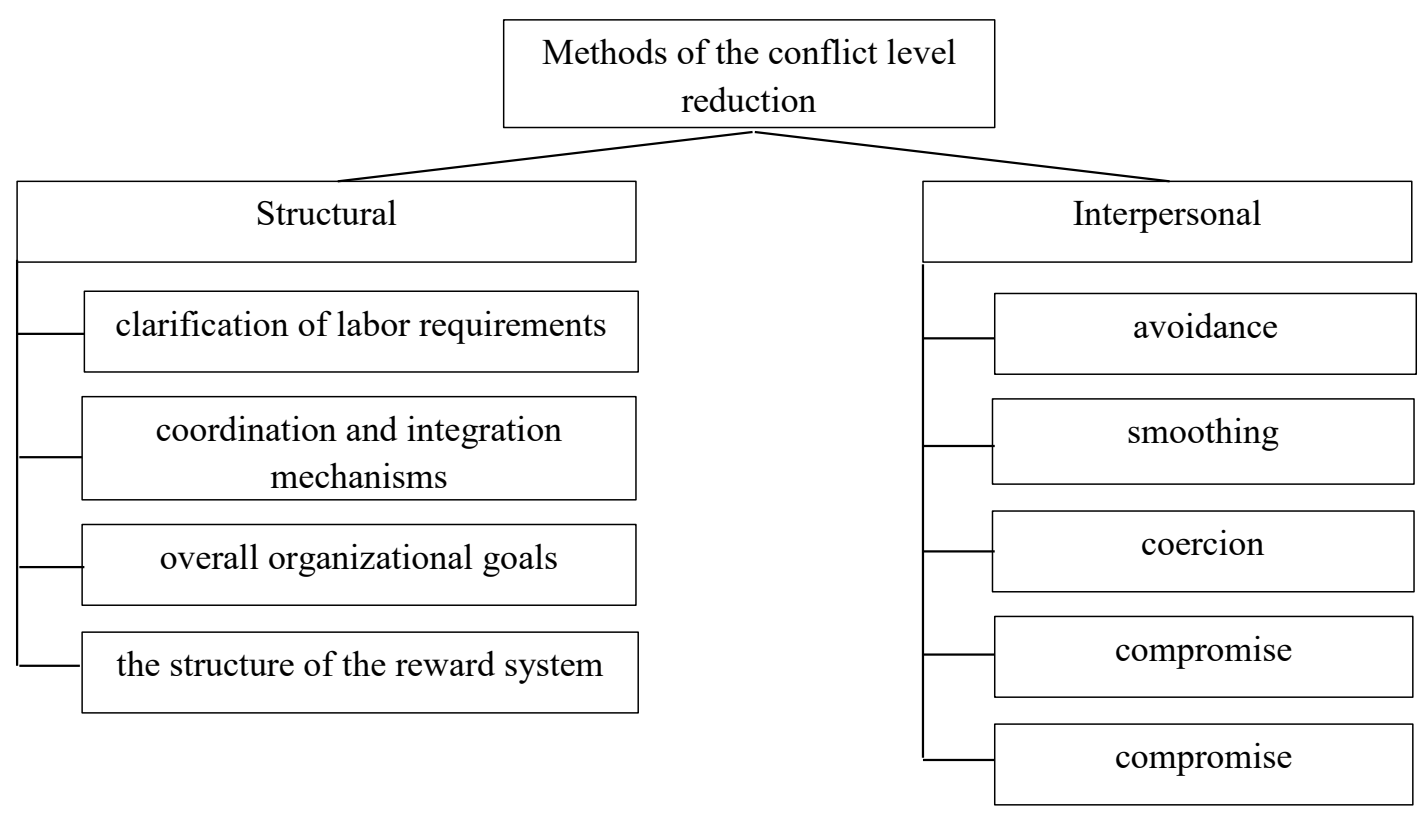

Figure 1. Methods of the conflict level reduction

Source: [10]

In order to obtain an objective and comprehensive assessment of the situation, it is desirable: to listen impartially to all participants in the conflict situation, without drawing premature conclusions; focus on the subject of the conflict situation and its initiators; bring together the participants in the conflict situation and lose the conflict process, while intervening or not interfering in it depending on the results [11].

Timely diagnosis of interpersonal conflicts is important both for their prevention and for constructive resolution. In order to prevent destructive conflicts between employees, it is necessary to know the nature of relationships in the team, to have information about trends in their development, to see employees who have difficulty communicating with colleagues, to help them build relationships.

Diagnosis of interpersonal conflicts in the group can be conducted using modular methods [12, p. 167-176]. It allows to collect a significant amount of information. The technique allows to identify the absolute and relative number of conflict interactions (dyads). Due to this technique, a conflict is a dyad of respondents who are in a state of real conflict, i.e. when opponents oppose each other and experience negative emotions towards each other. If each of them simply has a negative attitude towards the other, it may indicate not only the conflict, but also the pre-conflict situation in their relationship. In addition, the employee may treat his colleague negatively, but the latter will not consider his attitude as such, he may believe that this member of the group treats him well. The opposite phenomenon may occur: a positive attitude will be assessed as negative.

The index of conflict $(C)$ in the group is determined by the formula:

$$
\mathrm{C}=\frac{\sum_{\mathrm{i}=1}^{\mathrm{n}}(\mathrm{MO}+\mathrm{OM})}{\mathrm{n} \times(\mathrm{n}-1)},
$$

where $n$ is number of group (company) members;

$M O$ is assessment by specified person who filled his attitude to the person indicated in the list under number i as negative;

$O M$ is assessment of the specified respondents, the attitude to him by the $i$-th person in the list as negative.

The value of this indicator should be minimal for the determining the level of conflict in the company as low.

A study of a small company with 18 employees found that the index of conflict is almost 0.7. This indicates a very high level of conflict in the company. Analysis of employees' answers to the questions using tests developed for this study, as well as using the above methodology allowed to determine that the biggest problem in the company is a negative attitude towards the head of the company and his attitude to staff.

Together with the index of conflict it was determination type of the organizational culture in this company. For this the, the generally accepted in classical Western management typology of cultures proposed by J. Sonnenfeld and B. Agle 
[13]. Due to it the four types of organizational structure can be identified:

(1) "Academy Culture" is defined when employees have their own specialization, in which they improve their skills and develop their personality due to the conditions created by the organization.

(2) "Baseball Team Culture" occurs in a situation where risky decisions are made, a direct connection with the external environment is realized, business decisions are made very quickly, and at the same time employees change quickly.

(3) "Club Culture" characterized by loyalty, devotion and diligence, teamwork. Employees, coming young, work long hours and gradually move up the career ladder.

(4) "Fortress Culture" occurs in risky situations when the organization faces the problem of survival. There is no guarantee of permanent work and opportunities for professional growth, at the same time the confidence of employees in their abilities is formed.

According to J. Sonnenfeld's classification, the organizational culture in the studied company belongs to the type of "club culture", as career perspectives can only be received by employees of the company, and career growth is very slow and gradual.

Summing up, it is possible to say that the company has a strong enough organizational culture, but even it has enough negative aspects that significantly increase the level of conflict in the team. And the presence of conflicts in the team significantly reduces the cohesion in the company.

The following negative moments are observed in the researched company:

(1) in the organization there is a focus only on the result. On the one hand, this is not bad, but in the pursuit of profit, management forgets about the human factor - the personnel. This leads to inconsistency with the strategic goals of the company, because the main its goal is development, and to achieve it impossible without some investment in staff;

(2) rules and regulations are imposed by management without the consent of the staff. They are primarily aimed at discipline and concentration of employees only at work;

(3) the presence of a large number of rituals that are more formal in nature, and do not aim to strengthen the corporate spirit and maintain the corporate culture of the organization;

(4) the hierarchy of values accepted in the company is adapted to the economic conditions of Europe and has nothing to do with the Ukrain- ian reality. Hence the discrepancy between the interests of employees and the rules and regulations developed by management.

Based on the given results, to decrease the level of conflict for improving the organizational culture, it is proposed to introduce the following measures [14]:

(1) The cancelling the rules of the working day, according to which employees are prohibited from any interpersonal contact, except for working hours. This will allow colleagues to know each other better, to show teamwork skills, that is, work behavior will become clearer and, as a result, the approach to a specific employee will be understandable.

(2) Leadership should be allowed to develop their traditions and norms in the team without imposing them against their will. Performing common rituals will increase team cohesion. The lack of enforcement of certain rules will increase the independence of the team.

(3) Training the chief. The analysis of the level of conflict in the company shown a negative attitude of the staff towards the manager was found, as well as a negative attitude towards subordinates. In fact, the manager should not get out of the conflict, he should try to prevent, and if it is impossible to prevent, intervene to successfully manage and resolve such situations.

(4) Creation of a working team by influencing the personality of the leader. In most cases, these teams are staffed with research, product manufacturing, sales, customer service, and most of the work that adds value to the product.

(5) Implementation of a "code of conduct" in conflict to achieve rational behavior in the organization.

The implementation of these measures in the studied company will have a number of positive results: formation of understanding and awareness of the general company's goals and objectives and their relationship with the personal employees' goals and objectives; improving the psychological climate, increasing efficiency and discipline, as well as strengthening employee loyalty; identifying and resolving the existing interpersonal conflict situations, improving of personal relationships between employees; improving the authority of the head of the company; change of behavioral styles in conflict situations of employees to more constructive ones; application of skills acquired during the training in practice.

Conclusions. The management of modern companies needs to focus on conflict management. But along with this, the issues of organizational culture are also very important. The com- 
pany should find an individual approach to each member of the team. This can reduce the level of conflict in the company and to improve the organizational culture. The personnel of modern companies work in rather unstable conditions, there is a high risk of job loss, and job satisfac- tion is not always achieved due to low wages, the organizations have a fairly high level of conflict. To reduce it, the company should implement the measures to improve the leader skills in the conflict resolution and to increase the group cohesion in the company.

\section{REFERENCES:}

1. Monastyrs'kyj, H.L. (2007). Teoriia orhanizatsii [Theory of organization]. Ternopil: Ekonomichna dumka. (in Ukrainian)

2. Mel'nyk, A.O. (2018). Rol' motyvatsijnoi funktsii v orhanizatsijnij kul'turi [The role of the motivational function in organizational culture]. In O.V. Mazorenko (Ed.), Proceedings from: Mizhnarodna naukovo-praktychna konferentsiia «Suchasni problemy upravlinnia pidpryiemstvamy: teoriia ta praktyka» - International scientific conference «Modern problems of the enterprise management: theory and practice» (Kharkiv, March 29-30't 2018), pp. 74-76. Kharkiv: Vydavets' FOP Mezina. (in Ukrainian)

3. Brown, A. (1992). Organizational Culture: The Key to Effective Leadership and Organizational Development. Leadership \& Organization Development Journal, 13(2), 3-6. https://doi.org/10.1108/01437739210009545

4. Sazonova, T.O., Shul'zhenko, I.V. \& Khavroniuk, V.Yu. (2020). Upravlinnia konfliktamy iak vazhlyvyj element orhanizatsijnoi kul'tury suchasnoi orhanizatsii [Conflict management as an important element of the organizational culture of a modern organization]. Infrastruktura rynku - Market infrastructure, 47, 101-105. Retrieved from: http://www.market-infr.od.ua/journals/2020/47_2020_ukr/21.pdf. https://doi.org/10.32843/infrastruct47-19 (in Ukrainian)

5. Honchar, M.F. \& Bilyk, Yu.V. (2017). Osoblyvosti upravlinnia u stresovykh sytuatsiiakh. Stres-menedzhment na pidpryiemstvi [Features of management in stressful situations. Stress management at the enterprise]. Naukovyj visnyk NLTU Ukrainy. Ekonomichna seriia - Scientific Bulletin of NLTU of Ukraine, 27(2), 93-97. (in Ukrainian)

6. Shul'zhenko, I.V., Sarafannikov, V.V. \& Sobakar, S.V. (2017). Rol' kerivnyka v upravlinni konfliktamy na pidpryiemstvi [The role of the leader in conflict management in the enterprise]. Hlobal'ni ta natsional'ni problemy ekonomiky - Global and national economic problems, 20, 670-673. Retrieved from: http://global-national.in.ua/ archive/20-2017/137.pdf (in Ukrainian)

7. Prymush, M. (2006). Konfliktolohiia [Conflictology]. Kyiv: Vydavnychyj dim «Profesional». (in Ukrainian)

8. Coser, L. (1957). Social Conflict and the Theory of Social Change. The British Journal of Sociology, 8(3), 197-207. Retrieved from: https://www.jstor.org/stable/586859?seq=1

9. Borodkin, F. \& Korjak, N. (2013). Vnimanie: konflikt! [Attention: conflict!]. Moscow: Nauka. (in Russian)

10. Mel'nyk, P.V., Filonenko, M.M. \& Hats'ka, L.P. (2001). Menedzhment [Management]. Irpin': Akademiia DPS Ukrainy. (in Ukrainian)

11. Leonov, N.I. (2006). Konfliktologija [Conflictology]. Moscow: Izdatel'stvo Moskovskogo psihologo-social'nogo instituta; Voronezh : Izdatel'stvo NPO «MODJeK». (in Russian)

12. Ancupov, A.Ja. \& Shipilov, A.I. (2009). Konfliktologija [Conflictology]. Moscow: JuNITI-DANA. (in Russian)

13. Sonnenfeld, J.a. \& Agle, B. R. (1998). A Study of the Cultural Effects of Industry and Career Systems on Top Executive Perceptions of Ethical Problems. International Journal of Value-Based Management, 11, 73-91. https://doi.org/10.1023/A:1007770414323

14. Myronova, O. (2020). Measures to decreasing the conflict level in an organization. In O.V. Mazorenko (Ed.), Proceedings from: International scientific conference «Modern problems of the enterprise management: theory and practice», (Kharkiv - Torun, March 3-4, 2020), pp. 18-21. Kharkiv: FOP Panov A.M.

\section{СПИСОК ВИКОРИСТАНИХ ДЖЕРЕЛ:}

1. Монастирський Г.Л. Теорія організації. (Навчально-методичний комплекс). Тернопіль : Економічна думка, 2007.

Мельник А.О. Роль мотиваційної фрункції в організаційній культурі. О.В. Мазоренко (Відп. ред.). Міжнародна науково-практична конференція «Сучасні проблеми управління підприємствами: теорія та практика» (м. Харків, 29-30 березня 2018 р.), с. 74-76. Харків: Видавець ФОП Мезіна, 2018.

2. Brown, A. Organizational Culture: The Key to Effective Leadership and Organizational Development. Leadership \& Organization Development Journal. 1992. 13(2). 3-6. https://doi.org/10.1108/01437739210009545

3. Сазонова Т.О., Шульженко І.В., Хавронюк В.Ю. Управління конфрліктами як важливий елемент організаційної культури сучасної організації. Інсрраструктура ринку. 2020. 47. 101-105. Режим доступу: 
http://www.market-infr.od.ua/journals/2020/47_2020_ukr/21.pdf (дата звернення: 28.03.2021). https://doi.org/ 10.32843/infrastruct47-19

4. Гончар М.Ф., Білик Ю.В. Особливості управління у стресових ситуаціях. Стрес-менеджмент на підприємстві. Науковий вісник НЛтУ України. Економічна серія. 2017. 27(2). 93-97.

5. Шульженко І.В., Сарафранніков В.В., Собакар С.В. оль керівника в управлінні консрліктами на підприємстві. Глобальні та національні проблеми економіки. 2017. 20. 670-673. Режим доступу: http://global-national.in.ua/ archive/20-2017/137.pdf (дата звернення: 12.09.2020).

6. Примуш М. Консрліктологія. Київ : Видавничий дім «Професіонал», 2006.

7. Coser, L. Social Conflict and the Theory of Social Change. The British Journal of Sociology. 1957. 8(3). 197-207. Режим доступу: https://www.jstor.org/stable/586859?seq=1 (accessed 30 March 2021).

8. Бородкин Ф., Коряк Н. Внимание: конфрликт! Москва : Наука, 2013.

9. Мельник П.В., Філоненко М.М., Гацька Л.П. Менеджмент. Ірпінь : Академія ДПС України, 2001.

10. Леонов Н.И. Конфрликтология. Москва : Издательство Московского психолого-социального института; Воронеж : Издательство НПО «МОДЭК», 2006.

11. Анцупов А.Я., Шипилов А.И. Консрликтология. Москва : ЮНИТИ-ДАНА, 2009.

12. Sonnenfeld, J.A. \& Agle, B. R. A Study of the Cultural Effects of Industry and Career Systems on Top Executive Perceptions of Ethical Problems. International Journal of Value-Based Management. 1998. 11. 73-91. https://doi.org/10.1023/A:1007770414323

13. Myronova, O. Measures to decreasing the conflict level in an organization. In O.V. Mazorenko (Ed.). International scientific conference «Modern problems of the enterprise management: theory and practice», (KharkivTorun, March 3-4, 2020), pp. 18-21. Kharkiv : FOP Panov A.M., 2020. 